\title{
Anticancer effects against colorectal cancer models of chloro(triethylphosphine)gold(I) encapsulated in PLGA-PEG nanoparticles
}

\author{
Alessio Menconi • Tiziano Marzo (D) - Lara Massai $(\mathbb{D} \cdot$ Alessandro Pratesi $(\mathbb{D} \cdot$ \\ Mirko Severi - Giulia Petroni - Lorenzo Antonuzzo - Luigi Messori (iD) \\ Serena Pillozzi · Damiano Cirri $(\mathbb{D}$
}

Received: 10 October 2020/Accepted: 21 April 2021/Published online: 27 April 2021

(C) The Author(s) 2021

\begin{abstract}
Chloro(triethylphosphine)gold(I), (Et ${ }_{3-}$ $\mathrm{PAuCl}$ hereafter), is an Auranofin (AF)-related compound showing very similar biological and pharmacological properties. Like $\mathrm{AF}, \mathrm{Et}_{3} \mathrm{PAuCl}$ exhibits potent antiproliferative properties in vitro toward a variety of cancer cell lines and is a promising anticancer drug candidate. We wondered whether $\mathrm{Et}_{3} \mathrm{PAuCl}$ encapsulation might lead to an improved pharmacological profile also considering the likely reduction of unwanted side-reactions that are
\end{abstract}

Serena Pillozzi and Damiano Cirri have equally contributed to this study.

Supplementary Information The online version contains supplementary material available at https://doi.org/10.1007/ s10534-021-00313-0.

A. Menconi · G. Petroni · S. Pillozzi ( $)$

Department of Experimental and Clinical Medicine,

University of Florence, Viale G.B. Morgagni 50,

50134 Firenze, Italy

e-mail: serena.pillozzi@unifi.it

T. Marzo $(\square)$

Department of Pharmacy, University of Pisa, Via

Bonanno Pisano 6, 56126 Pisa, Italy

e-mail: tiziano.marzo@unipi.it

L. Massai · M. Severi · L. Messori

Laboratory of Metals in Medicine (MetMed), Department

of Chemistry "U. Schiff”, University of Florence, Via

della Lastruccia 3, 50019 Sesto Fiorentino, Italy responsible for adverse effects and for drug inactivation. $\mathrm{Et}_{3} \mathrm{PAuCl}$ was encapsulated in biocompatible PLGA-PEG nanoparticles (NPs) and the new formulation evaluated in colorectal HCT-116 cancer cells in comparison to the free gold complex. Notably, encapsulated $\mathrm{Et}_{3} \mathrm{PAuCl}$ (nano- $\mathrm{Et}_{3} \mathrm{PAuCl}$ hereafter) mostly retains the cellular properties of the free gold complex and elicits even greater cytotoxic effects in colorectal cancer (CRC) cells, mediated by apoptosis and autophagy. Moreover, a remarkable inhibition of two crucial signaling pathways, i.e. ERK and AKT, by nano- $\mathrm{Et}_{3} \mathrm{PAuCl}$, was clearly documented. The implications of these findings are discussed.

Keywords PLGA-PEG nanoparticles - Auranofin . Anticancer complexes · Colorectal cancer

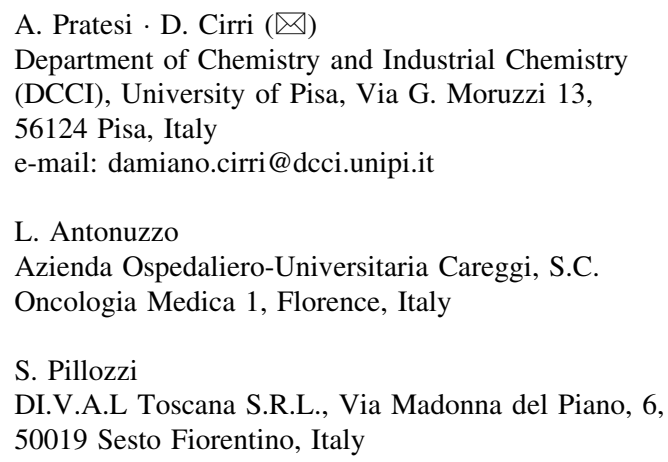




\section{Introduction}

Auranofin (AF) is an established gold(I) drug for the treatment of rheumatoid arthritis, in clinical use since 1986 (Bombardier et al. 1986). In the last decade, AF and in general gold-based compounds, have been extensively reconsidered as potential anticancer agents characterized by an original and DNA-independent mode of action (Pratesi et al. 2014; Micale et al. 2014; Marzo et al. 2017; Magherini et al. 2018; Scalcon et al. 2018). The first papers on AF and its anticancer activity revealed that this gold complex is an effective agent in vitro toward melanoma and leukaemia cells (Mirabelli et al. 1985); its activity toward ovarian and non-small-cell lung cancer cells was later documented (Roder and Thomson 2015; Li et al. 2016). It is now widely recognized that the pharmacologically active portion of the AF molecule is the cationic fragment $\left[\mathrm{Au}\left(\mathrm{PEt}_{3}\right)\right]^{+}$(Pratesi et al. 2018; Zoppi et al. 2020) while the thiosugar moiety mainly acts as a carrier ligand improving the bioavailability and the gold complex pharmacokinetic profile when orally administered (Marzo et al. 2017). Based on these arguments, recently, we started a systematic and comparative evaluation of a series of AF-related compounds (Marzo et al. 2017, 2018; Tolbatov et al. 2020). Our attention was firstly focused on AF-related complexes where the thiosugar moiety is replaced by halide ligands. Interestingly, two of them-i.e. $\mathrm{Et}_{3-}$ $\mathrm{PAuCl}$ and Iodo(triethylphosphine)gold(I)-manifested a fully retained or even improved anticancer activity toward colorectal and ovarian cancer cells (Marzo et al. 2017, 2019). Since $\mathrm{Et}_{3} \mathrm{PAuCl}$ possesses a pharmacological profile closely resembling AF (Sutton et al. 1972), it is plausible-at least in principle- to further enhance its pharmacological actions by reducing those unwanted ("off target") side reactions that often limit drug bioavailability/cellular distribution. Indeed, the Au centre can react with sulphur-containing solvent exposed aminoacidic residues of serum proteins (Zoppi et al. 2020).

Among several approaches, to achieve this goal, a reasonable strategy is given by the preparation of biocompatible nanostructures as smart platforms for drug delivery. Indeed, the use of biocompatible nanocarriers is widely recognized as a very promising strategy for pharmaceutical applications (Afshari et al. 2014; Johnstone et al. 2016; Anari et al. 2016; Merlino et al. 2017). Thus, we have explored whether the activity of $\mathrm{Et}_{3} \mathrm{PAuCl}$ toward $\mathrm{CRC}$ cells might be enhanced by encapsulation of this compound in fluorescent PLGA-PEG nanoparticles bearing a rhodamine fluorophore for tracking (Cheng et al. 2007; Tian et al. 2017; Poursharifi et al. 2018). A detailed and comparative characterization of the anticancer effects of these constructs has been carried out in 2D or $3 \mathrm{D}$ cell cultures, highlighting the promising features of this novel $\mathrm{Et}_{3} \mathrm{PAuCl}$-encapsulated formulation.

\section{Materials and methods}

All the reagents were provided by Merck-Sigma Aldrich and used without further purification. $\mathrm{Et}_{3-}$ $\mathrm{PAuCl}$ was purchased from Sigma-Aldrich (code: 288225). Solvents were also used without further purification.

Preparation of polymeric matrix

PLGA-C=O-NH-PEG-COOH: $251 \mathrm{mg}$ of 50:50 PLGA (mw 7000-17,000 g/mol; $0.021 \mathrm{mmol}$ ) were solubilised in $8 \mathrm{~mL}$ of anhydrous dichloromethane. $14 \mathrm{mg}$ of $\mathrm{EDC} \cdot \mathrm{HCl}$ (1-ethyl-3-(3-dimethylaminopropyl)carbodiimide hydrochloride $)(0.073 \mathrm{mmol})$ were added to the solution under stirring. After $10 \mathrm{~min} 7 \mathrm{mg}(0.061 \mathrm{mmol})$ of N-Hydroxysuccinimide were also added. After $1 \mathrm{~h}, 77 \mathrm{mg}$ of $\mathrm{H}_{2} \mathrm{~N}-$ PEG-COOH $(3400 \mathrm{~g} / \mathrm{mol})$ and $7 \mu \mathrm{L}$ of N,N-Diisopropylethylamine were then added. The solution was stirred at room temperature for $18 \mathrm{~h}$. Next, the solvent was evaporated under reduced pressure. The crude product was solubilized with $10 \mathrm{~mL}$ of chloroform, then the solution was washed twice with $10 \mathrm{~mL}$ of brine. The organic phase was dried with $\mathrm{MgSO}_{4}$ and filtered. The desired product was obtained after prolonged evaporation of solvent under reduced pressure (242 mg; $0.017 \mathrm{mmol}$; $81 \%$ yield). ${ }^{1} \mathrm{HNMR}$ is consistent with the data already reported in literature (Cheng et al. 2007) (see Fig. 1).

$\mathrm{RhB}-\mathrm{C}=\mathrm{O}-\mathrm{PLGA}-\mathrm{C}=\mathrm{O}-\mathrm{NH}-\mathrm{PEG}-\mathrm{COOH}:$ In a $50 \mathrm{~mL}$ flask were added $41 \mathrm{mg}$ of Rhodamine B, $8 \mathrm{~mL}$ of anhydrous dichloromethane, $242 \mathrm{mg}$ of PLGA-PEG-COOH $(0.017 \mathrm{mmol})$ previously synthesized, $19 \mathrm{mg}(0.099 \mathrm{mmol})$ of $\mathrm{EDC} \cdot \mathrm{HCl}$ and $9.5 \mu \mathrm{L}(0.05 \mathrm{mmol})$ of N,N-Diisopropylethylamine. The reaction mixture was stirred at r.t. for $18 \mathrm{~h}$, then the suspension was dried under reduced pressure. The 




Fig. 1 Schematic representation for the preparation of the loaded PLGA-PEG nanoparticle. a PLGA-PEG polymer covalently functionalized with the Rhodamine B fluorescent probe; b the yellow spheres represent $\mathrm{Et}_{3} \mathrm{PAuCl}$; c the nanoparticle after gold complex loading

crude product was solubilized with $5 \mathrm{~mL}$ of dichloromethane and the solution was washed with $10 \mathrm{~mL}$ of brine. The organic phase was dried with $\mathrm{MgSO}_{4}$ and filtered. The volume was reduced with rotary evaporator and $2 \mathrm{~mL}$ of methanol were added. The product was finally dried under reduced pressure and $191 \mathrm{mg}$ of rhodaminated PLGA were obtained $(0.013 \mathrm{mmol}$; yield $76 \%)$.

${ }^{1} \mathrm{HNMR}\left(400.13 \mathrm{MHz} ; \mathrm{CDCl}_{3}\right): 7.98(\mathrm{~d} ; 7.56 \mathrm{~Hz}$; RhB moiety); 7.62 (dt; RhB moiety); 7.56 (dt; RhB moiety); 7.20 (d; 7.50 Hz; RhB moiety); 6.54 (m: RhB moiety); 6.43 (m; RhB moiety); 6.32 (m; RhB moiety); 5.20 (b; $\mathrm{CH}$ lactic moiety); 4.81 (m; $\mathrm{CH}_{2}$ glycolic moiety); 3.64 (s; PEG moiety); 3.5 (q; $7.07 \mathrm{~Hz} ; \mathrm{RhB}$ ); 1.57 (m; $\mathrm{CH}_{3}$ lactic moiety); 1.16 (t; $7.05 \mathrm{~Hz}$; RhB) (Fig. S1).

\section{Nanoparticles preparation}

The particles were precipitated by solubilization of the polymeric matrix in acetonitrile at the concentration of $5 \mathrm{mg} / \mathrm{mL}$ in presence of $1 \%$ (weight) of $\mathrm{Et}_{3} \mathrm{PAuCl}$ by dropwise addition of the solution to $4 \times$ volume of stirring water. $2.24 \mathrm{mg}$ of $\mathrm{Et}_{3} \mathrm{PAuCl}$ were solubilized in $4.48 \mathrm{~mL}$ of acetonitrile. $1 \mathrm{~mL}$ of the obtained solution $(1.43 \mathrm{mM})$ was diluted to $10 \mathrm{~mL}$ with acetonitrile to a final concentration of $0.143 \mathrm{mM}$. Afterward, $1 \mathrm{~mL}$ of this latter solution was used to solubilize $5.8 \mathrm{mg}$ of polymeric matrix. The obtained solution was added dropwise into $4 \mathrm{~mL}$ of stirring water and the organic solvent removed by evaporation under reduced pressure for $40 \mathrm{~min}$. After the evaporation process, $3.6 \mathrm{~mL}$ of an aqueous suspension of $\mathrm{Et}_{3} \mathrm{PAuCl}$ loaded nanoparticles were obtained. The final concentration of $\mathrm{Et}_{3} \mathrm{PAuCl}$, determined through ICP-AES analysis, was $0.04 \mathrm{mM}$ (Cheng et al. 2007; Park et al. 2008; Tian et al. 2017; Poursharifi et al. 2018).

\section{Spectroscopic properties}

Absorption proprieties were investigated using an UV-Vis CaryBio50 spectrophotometer. A suspension of $246 \mu \mathrm{g} / \mathrm{mL}$ was investigated for determining the $\lambda$ of maximum absorbance $(562 \mathrm{~nm})$. To further asses the complete binding of the rhodamine dye to the polymeric structure, UV-Vis analysis was repeated on the nanoparticle solution (at the above concentration) after centrifugation using $100 \mathrm{kDa}$ nominal cut-off Amicon filter. To this end $5 \mathrm{~mL}$ of solution were centrifuged for 2 min at 4428 RCF. Next, the filtered solution was investigated trough absorbance experiments revealing only tiny traces of unbounded rhodamine (Fig. S2A). For a better quantification of unbounded rhodamine, the previous prepared samples were analyzed through luminescence emission experiments using a Perkin Elmer LS55 fluorescence spectrometer. Analysis were performed with an excitation wavelength of $530 \mathrm{~nm}$ (Fig. S2B). Through a comparison between the heights of fluorescence emission spectra, we deduced that fluorescence emission due to unbounded dye was about the $6 \%$ of the total. The $\lambda$ of maximum fluorescence emission turned out to be $582 \mathrm{~nm}$.

\section{$\mathrm{Et}_{3} \mathrm{PAuCl}$ retention}

The retention of the loaded $\mathrm{Et}_{3} \mathrm{PAuCl}$ from nanoparticles was evaluated through ICP-AES spectroscopy. First of all, loaded nanoparticles were prepared as reported above. Then, after $24 \mathrm{~h}$ from the formation of nanoparticles, $5 \mathrm{~mL}$ of suspension were centrifuged in a $100 \mathrm{kDa}$ cut-off Amicon filter. The filtered solution was analyzed for determining the residual gold amount in comparison with initial addition of gold complex. The value of gold retention, obtained as a mean of analysis performed on three different batches, turned out to be $92.7 \%$ (Table S2). 
Gold complex solutions

For cellular experiments, $\mathrm{Et}_{3} \mathrm{PAuCl}$ was dissolved in DMSO at a concentration of $10 \mathrm{mM}$ being the complex very stable in this solvent (Marzo et al. 2017). The stock solution was stored at $-20^{\circ} \mathrm{C}$. The following solutions were prepared through accurate dilutions by adding RPMI medium. Instead, the nanoparticle solutions were dissolved in ultrapure water at a concentration of $40 \mu \mathrm{M}$. The stock solution was stored at $4{ }^{\circ} \mathrm{C}$.

ICP-AES experiments (uptake)

The Au concentration in cells was measured by a Varian 720-ES Inductively Coupled Plasma Atomic Emission Spectrometer (ICP-AES) equipped with a CETAC U5000 AT+ ultrasonic nebulizer, this latter allowing to increase the method sensitivity. Cellular pellets were digested in a thermo-reactor at $80{ }^{\circ} \mathrm{C}$ for $6 \mathrm{~h}$ with $6 \mathrm{~mL}$ of $30 \% \mathrm{HNO}_{3}$. Next, $5.0 \mathrm{~mL}$ of each sample were spiked with $1 \mathrm{ppm}$ of $\mathrm{Ge}$ used as an internal standard and analysed. Calibration standards were prepared by gravimetric serial dilution from a commercial standard solution of $\mathrm{Au}$ at $1000 \mathrm{mg} / \mathrm{L}$. The wavelength used for $\mathrm{Au}$ determination was $267.594 \mathrm{~nm}$ whereas for Ge the line at $209.426 \mathrm{~nm}$ was used. The operating conditions were optimized to obtain maximum signal intensity, and between each sample, a rinse solution of $\mathrm{HNO}_{3}$ suprapure grade was used in order to avoid any "memory effect".

Dynamic light scattering experiments (DLS)

Once prepared, the size of NPs was determined on the obtained suspension. To this end, Dynamic Light Scattering measurements were carried out on a Brookhaven BI 9000AT apparatus equipped with a Nd:YAG laser, Coherent Innova, $\lambda=532 \mathrm{~nm}$.

\section{Cell culture}

Human colorectal cancer (CRC) cell line HCT-116 was cultured in RPMI-1640 medium, and HEK 293 in DMEM (Euroclone; Milan, Italy), both medium supplemented with $10 \%$ fetal bovine serum (FBS). The cell lines were cultured at $37{ }^{\circ} \mathrm{C}$ in humidified atmosphere and $5 \% \mathrm{CO}_{2}$.
Cell viability assay

\section{Trypan blue assay}

The $50 \%$ inhibitory concentration $\left(\mathrm{IC}_{50}\right)$ of the tested compounds were determined by cell viability assay, through the Trypan blue exclusion test (SigmaAldrich). Cells were seeded in 96-well plates (Costar Corning) at $1 \times 10^{4}$ cells/well in RPMI complete medium. The cells were incubated for $24 \mathrm{~h}$ before adding the compounds at $0,50,75,100,150,175,200$, 250, 275 and $400 \mathrm{nM}$; after the administration of the compounds, cells were further incubated for $24 \mathrm{~h}$. Then, cells were harvested, and alive cells were counted using a hemocytometer. Data were mean values of the viable cell percentage of three independent experiments. The $\mathrm{IC}_{50}$ values were obtained by averaging the experiments and fitting with Hill1-type equation of Origin Software (Microcal Origin 8.0 software; Origin Lab Corporation, Northampton, MA).

\section{MTT assay}

Briefly, HCT116 were seeded into 96-well plates in a final concentration of 2000 cells/well and incubated for $24 \mathrm{~h}$ at $37{ }^{\circ} \mathrm{C}$. To test the toxicity, the cells in each well were treated with the compounds at 0,50,100 and $200 \mathrm{nM}$. After $24 \mathrm{~h}$ of incubation, cell viability was determined: $80 \mu \mathrm{L}$ of MTT-medium was added to each well for $4 \mathrm{~h}$. Then, the MTT solution was discard and $120 \mu \mathrm{L}$ of a 2-propanol/ $\mathrm{HCl}$ solution was added to dissolve the formazan crystals and the absorbance was measured at $490 \mathrm{~nm}$.

Morphology analysis

HCT-116 cells were seeded in 24-well plates at $4 \times 10^{4}$ cells/well in complete medium and incubated for $24 \mathrm{~h}$. Cells, treated for $24 \mathrm{~h}$ as well as before $(0$, $100,200 \mathrm{nM}$ ), were then harvested and their morphology was studied. Every condition was fixed on two spots of a histological slide using a refrigerated centrifuge to $728 \mathrm{RCF}$ for $5 \mathrm{~min}$. Afterwards, they were overnight dried at room temperature and stained with May-Grunwald Giemsa. Finally, we took images (Microscope Nikon Eclipse E200 with lens 40× ) and analyzed the effects in term of morphology alterations, using ImageJ software. 
Cell cycle analysis

The effect of $\mathrm{Et}_{3} \mathrm{PAuCl}$ and its encapsulated formulation were also measured on cell cycle distribution with flow cytometry, using a staining solution with propidium iodide [ $50 \mu \mathrm{g} / \mathrm{mL}$ propidium iodide, $0.1 \%$ [w/v] trisodium citrate, $0.1 \%$ NP40 (or triton $\mathrm{x}-100$ )]. HCT-116 cells were seeded in 24-well plates at a cell density of $3 \times 10^{4}$ cells per well, to which gold complexes were added at: 0, 100, $200 \mathrm{nM}$. Then, cells were incubated for $24 \mathrm{~h}$. At the end of incubation, cells were harvested and incubated in the staining solution for $30 \mathrm{~min}$ in the dark at $4{ }^{\circ} \mathrm{C}$. The DNA content of cells was assessed using a BD FACSCanto (Becton Dickinson, Franklin Lakes, NJ, USA) and the percentage of cells in each cell cycle phase was determined by the ModFit LT 3.0 analysis software.

\section{D Proliferation assay}

HCT-116 cells were culture in 96-well plates and it was seeded at a cell density of $1 \times 10^{4}$ per well in RPMI medium. After $24 \mathrm{~h}$ of incubation, cells were treated from 0 to $200 \mathrm{nM}$ and they were further incubated for $24 \mathrm{~h}, 48 \mathrm{~h}$ and $72 \mathrm{~h}$. Viable cells were determined using the Trypan Blue exclusion as described above. All experiments were performed in triplicate for each data point.

\section{Western blot analysis}

Proteins were separated by $7.5 \%$ gel and electroblotted on PVDF membranes, following a general protocol. The membranes were blocked in 5\% BSA in TPBS for $3 \mathrm{~h}$ at room temperature, incubated overnight in the primary antibody solutions at $4{ }^{\circ} \mathrm{C}$, incubated in the corresponding peroxidase-conjugated secondary antibody solution for $1 \mathrm{~h}$ at room temperature and added ECL to achieve the chemiluminescent signals. The following primary antibodies were used for WBs, at the indicated concentrations. The rabbit $\mathrm{pAb}$ against phospho-44/42 MAPK (Erk1/2) (Thr202/Tyr204, \#9101; dilution 1:1000) were purchased from Cell Signaling Technology. The mouse mAb against phospho-AKT1/2/3 (clone B-5, sc-271966; dilution 1:500), the rabbit pAb against AKT1/2/3 (clone $\mathrm{H}-136$, sc8312; dilution 1:500), and the rabbit pAb against ERK1/2 (clone H-72, sc-292838; dilution 1:200) were purchased from Santa Cruz
Biotechnology. Anti-rabbit IgG peroxidase conjugated (A0545; dilution 1:10,000) and anti-mouse IgG peroxidase antibodies (A4416; dilution 1:5000) were used as secondary antibodies.

\section{D Proliferation assay}

Multicellular tumor spheroids were obtained by HCT116 cells seeding the cells on 96-wells plate after coating the wells with a solution of sterile agarose $1.5 \%$. After coating, cells were added at $1 \times 10^{3}$ cells per well in complete medium. The plate was placed in the incubator at $37{ }^{\circ} \mathrm{C}$ and $5 \% \mathrm{CO}_{2}$ for $72 \mathrm{~h}$ to allow the formation of three-dimensional (3D) spheroids. Next, we treated the cells with the two compounds at 0 , $200 \mathrm{nM}$ and we registered digital images of every spheroid at different time, starting from 0 to $144 \mathrm{~h}(0$, $24,48,72,96,120,144 \mathrm{~h}$ ). We obtained images using a camera equipped with the microscope, $10 \times$ magnification. Every image exhibited a spheroid, whose volume could be used as a measure of the efficacy for our in vitro cancer drug analysis. Spheroid volume, determined based on the major and minor axial length of the spheroids $\left(\mathrm{V}=0.5 \times\right.$ Length $\times \mathrm{Width}^{2}$ ), were automatically calculated by SpheroidSizer1_0, a MATLAB-based and open-source software (MATLAB 2015a, MathWorks Inc.). Finally, the relative volumes were determined relating every volume to its value at time 0 . The relative volumes allowed to evaluate spheroid proliferations (Chen et al. 2014).

\section{Fluorescence analysis}

HCT-116 cells were seeded at $3 \times 10^{4}$ on cell culture dishes $35 \mathrm{~mm}$ in RPMI medium and incubated $24 \mathrm{~h}$. Afterwards, cells were treated at 0 and $200 \mathrm{nM}$ with only $\mathrm{Et}_{3} \mathrm{PAuCl}$ encapsulated and they were harvested at $1 \mathrm{~h}, 2 \mathrm{~h}, 4 \mathrm{~h}$ after the administration. They were then fixed with formalin solution (formalin $10 \%$ in PBS) for $10 \mathrm{~min}$ and they were resuspended in PBS. Every cell culture dish was stored at $4{ }^{\circ} \mathrm{C}$. The sequestration of nanoparticles by HCT-116 was quantified in term of fluorescence, thanks to the fluorescent Rhodamine B covalently linked to PLGAPEG nanoparticles using a fluorescence microscopy [Nikon Eclipse TE300 microscope (Nikon Instruments Inc.), equipped with a Photometrics CoolSNAP CF camera (Teledyne Photometrics, Tucson AZ)]. 
Brightfield and fluorescence images were both collected and analyzed measuring cell fluorescence using ImageJ software. We calculated the corrected total cell fluorescence (CTCF) using the values of integrated density (IntDen hereafter) and performing the following calculation: CTCF $=$ IntDen $-($ Area of selected cell $\times$ Mean fluorescence of background readings).

\section{Results and discussion}

The loaded nanoparticles were prepared following the already established procedures (Cheng et al. 2007; Park et al. 2008; Tian et al. 2017; Poursharifi et al. 2018) as described in the experimental section. These particles are composed of a hydrophobic PLGA core surrounded by a hydrophilic PEG layer acting both as a solubilizing and a capping agent. A quite homogeneous monodispersed preparation of PLGA-PEG nanoparticles was obtained with an average size (derived from the hydrodynamic radius) of $65 \mathrm{~nm}$ (Table S1 supporting material). Noteworthy, the protocol used for the encapsulation process is rapid and nearly quantitative. The average content of gold inside nanoparticles was determined through ICPAES spectroscopy; we found that $92.7 \%$ of total added gold (after $24 \mathrm{~h}$ ) was incorporated inside nanoparticles indicating the high stability of the loaded nanoparticles and making them well suitable for the biological testing (see supporting information Table S1 and experimental section).

$\mathrm{Nano}-\mathrm{Et}_{3} \mathrm{PAuCl}$ was assessed comparatively with the free gold complex for the biological effects in HCT-116 2D and 3D cell models and the distribution evaluated through fluorescence experiments (Chen et al. 2014).

Firstly, we determined the effects of nano-Et ${ }_{3-}$ $\mathrm{PAuCl}$ in comparison to free $\mathrm{Et}_{3} \mathrm{PAuCl}$ on the viability of human CRC cells (HCT-116) after exposure to increasing concentrations of these compounds within the $0-400 \mathrm{nM}$ range. After $24 \mathrm{~h}$ of treatment, $\mathrm{IC}_{50}$ values were determined (calculated through the Trypan blue exclusion test) and both nano- $\mathrm{Et}_{3} \mathrm{PAuCl}$ and $\mathrm{Et}_{3} \mathrm{PAuCl}$ were able to reduce the viability of HCT116 cells, in a dose-dependent manner, with nano$\mathrm{Et}_{3} \mathrm{PAuCl}$ being less effective (Fig. 2a).

In particular, the encapsulated form was less cytotoxic $\left(\mathrm{IC}_{50}=274 \mathrm{nM}\right)$ than $\mathrm{Et}_{3} \mathrm{PAuCl}\left(\mathrm{IC}_{50}\right.$ $=129 \mathrm{nM}$ ) (Fig. 2a). In addition, we investigated
Fig. 2 Nano-Et ${ }_{3} \mathrm{PAuCl}$ affects cell viability of human $\mathrm{CRC}$ cell line. a Curves and $\mathrm{IC}_{50}$ values $(\mathrm{nM})$ of $\mathrm{Et}_{3} \mathrm{PAuCl}$ and of its encapsulated form in HCT-116 cell line. Cell viability was measured after $24 \mathrm{~h}$ of treatment, by the Trypan Blue exclusion test. Curves and $\mathrm{IC}_{50}$ values resulted by means of six independent experiments and they were then calculated fitting the experimental data with Origin Software Hill1-type equation. b Representative bright field and fluorescence images of nanoparticles cellular distribution in cancer cell suspensions, using fluorescence microscopy. c Histogram of fluorescence analysis relative to corrected total cell fluorescence (CTCF) obtained by ImageJ software. Data are reported as means \pm SEM of 5-7 cells for each time point and every experimental condition was investigated in duplicate. The significance of differences between groups was calculated through $t$ test. ${ }^{*} \mathrm{p}<0.05 ;{ }^{* *} \mathrm{p}<0.01$. ['CTCF' (ctrl vs $1 \mathrm{~h}, \mathrm{p}=3.3 \times 10^{-5}$; ctrl vs $2 \mathrm{~h}, \mathrm{p}=9.3 \times 10^{-8}$; $\left.\left.\operatorname{ctrl} v s 4 \mathrm{~h}, \mathrm{p}=9.3 \times 10^{-10}\right)\right]$

$\mathrm{Et}_{3} \mathrm{PAuCl}$ and its nanoformulation on HCT-116 cell viability evaluated by MTT assay and the results were virtually identical (Fig. S3).

Despite that, we could observe that both compounds reduced drastically CRC cells viability compared to untreated cells, confirming for $\mathrm{Et}_{3} \mathrm{PAuCl}$ the previous data published by our group (Marzo et al. 2017) (control vs $\mathrm{Et}_{3} \mathrm{PAuCl} 50 \mathrm{nM}, \mathrm{p}=0.035$; control vs $\mathrm{Et}_{3} \mathrm{PAuCl} 100 \mathrm{nM}, \mathrm{p}=0.008$; control $v s \mathrm{Et}_{3} \mathrm{PAuCl}$ $200 \mathrm{nM}, \quad \mathrm{p}=0.014 ;$ control vs nano-Et ${ }_{3} \mathrm{PAuCl}$ $100 \mathrm{nM}, \mathrm{p}=0.049 ;$ control $v s$ nano- $\mathrm{Et}_{3} \mathrm{PAuCl}$ $200 \mathrm{nM}, \mathrm{p}=0.008)$. On the other hand, the cytotoxic active species, i.e. the free gold complex and its encapsulated formulation, when used at the same concentrations, barely affected the viability of normal human embryonic kidney cells (HEK 293), with IC $_{50}$ values greater than $1000 \mathrm{nM}$ as assessed by the same assay (data not shown).

Next, the nanoparticles cellular distribution was monitored by fluorescence microscopy being the PLGA-PEG nanoparticles covalently linked with fluorescent Rhodamine B. CRC cells (HCT-116) were treated for $1 \mathrm{~h}, 2 \mathrm{~h}$ and $4 \mathrm{~h}$ with nano- $\mathrm{Et}_{3} \mathrm{PAuCl}$ $(200 \mathrm{nM})$ and analysed under the fluorescence microscope at different time points and the corrected total cell fluorescence (CTCF) determined. We registered the presence of the NPs inside CRC cells already after $1 \mathrm{~h}$ with a CTCF value of $12,825 \pm 2008$; notably such value increases rapidly and linearly with the longer incubation times $(1 \mathrm{~h} 12,825 \pm 2008$ vs $2 \mathrm{~h}$

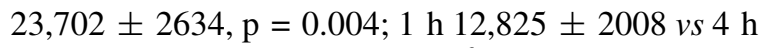
$\left.36,741 \pm 3245, p=5.78 \times 10^{-6}\right)($ Fig. $2 b$ and c). 

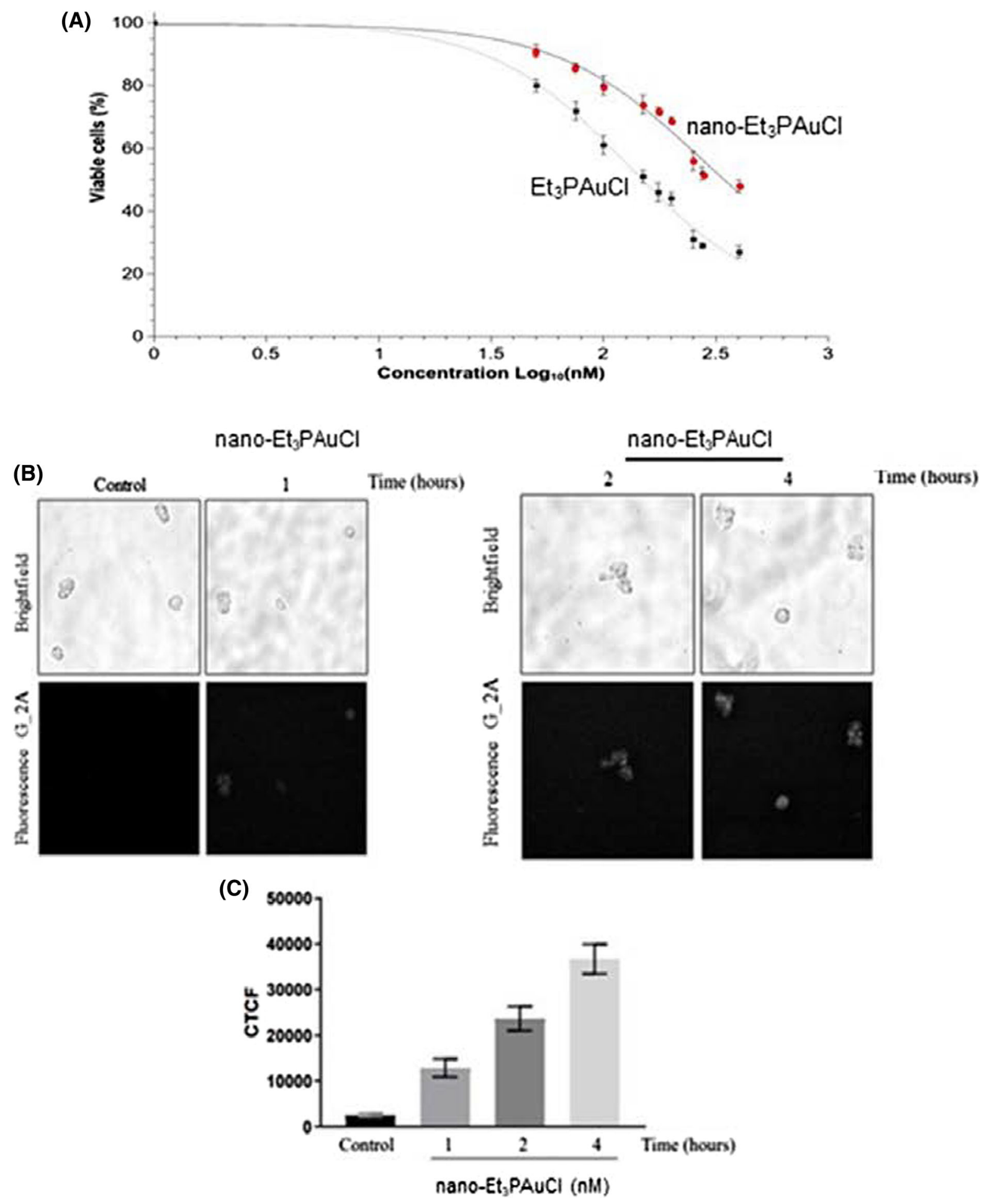
Table 1 Gold level (per cell) measured after exposure ( 3 and $24 \mathrm{~h}$ ) of HCT116 cells to $200 \mathrm{nM}$ of nano- $\mathrm{Et}_{3} \mathrm{PAuCl}$

\begin{tabular}{lll}
\hline Time $(\mathrm{h})$ & Concentration $(\mathrm{nM})$ & Au $(\mu \mathrm{g} / \mathrm{cell})$ \\
\hline 3 & 200 & $1.7522 \times 10^{-9}$ \\
24 & 200 & $1.6378 \times 10^{-8}$ \\
\hline
\end{tabular}

As independent confirmation of the ability of the loaded NPs to enter cells, we carried out ICP-AES experiments (Table 1) using an already established protocol developed in our laboratory (Cirri et al. 2017; Pillozzi et al. 2018).

The ICP results nicely support and the evidence already obtained with the fluorescence approach. In fact, we confirmed as NPs are already internalized after short incubation times $(3 \mathrm{~h})$. Analogously, the metal uptake increases of about one order of magnitude after $24 \mathrm{~h}$. In order to investigate in depth the cellular effects of the new formulation, we performed a morphological evaluation of CRC cells after $24 \mathrm{~h}$ of treatment: HCT-116 cells were treated with increasing concentrations of the free gold complex and its encapsulated form $(0,100 \mathrm{nM}$ and $200 \mathrm{nM})$ and stained with May-Grunwald Giemsa (Fig. 3, Table 2).

The effects were observed through May-Grunwald Giemsa staining and analyzed with ImageJ software. The analysis concerned 1012 cells per each condition, in triplicate, in term of: diameter, nucleus/cytoplasm ratio and vacuoles per cell. The significance of differences between groups was calculated through $t$ test. ${ }^{*} \mathrm{p}<0.05 ;{ }^{* *} \mathrm{p}<0.01$. [Diameter (ctrl $v s$ $\mathrm{Et}_{3} \mathrm{PAuCl} 100 \mathrm{nM}, \mathrm{p}=0.0009$; ctrl vs nano- $\mathrm{Et}_{3} \mathrm{PAuCl}$ $100 \mathrm{nM}, \mathrm{p}=2.6 \times 10^{-5}$ ); vacuoles/cells (ctrl vs $\mathrm{Et}_{3-}$ $\mathrm{PAuCl} 100 \mathrm{nM}, \mathrm{p}=0.0005$; ctrl vs nano-Et ${ }_{3} \mathrm{PAuCl}$ $100 \mathrm{nM}, \mathrm{p}=0.0016)]$.

Then, we analysed the dimensions of the treated cells in comparison to untreated cells: cells treated with $\mathrm{Et}_{3} \mathrm{PAuCl}(100 \mathrm{nM})$ showed a significant cell size reduction, calculated as the mean cell diameter with respect to control cells (control: $26.03 \mu \mathrm{m} \pm$ $\left.0.18 v s \mathrm{Et}_{3} \mathrm{PAuCl}: 24.57 \mu \mathrm{m} \pm 0.28, \mathrm{p}=0.0009\right)$, a key morphological feature of apoptosis, suggesting that the free compound does exert a pro-apoptotic effect on HCT-116 cells. Such reduction was more relevant in cells treated with nano- $\mathrm{AFCl}$ (at $100 \mathrm{nM}$ ) (control: $26.03 \mu \mathrm{m} \pm 0.18$ vs nano-Et $_{3} \mathrm{PAuCl}$ : $22.85 \mu \mathrm{m} \pm 0.46, \mathrm{p}=2.6 \times 10^{-5}$ ) that induces also

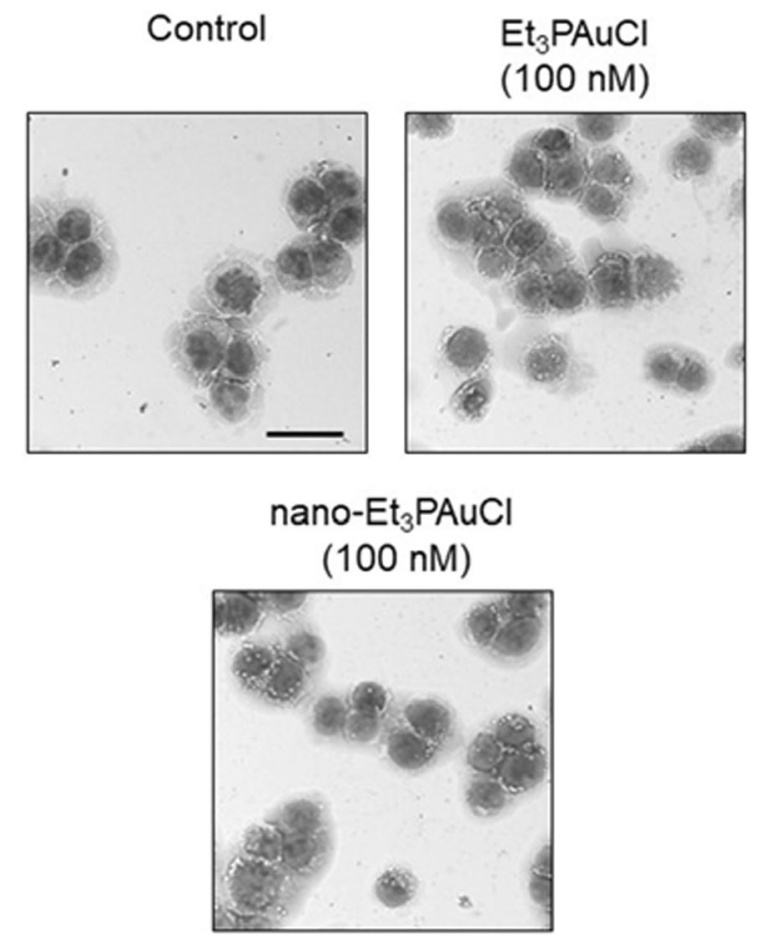

Fig. $3 \mathrm{Et}_{3} \mathrm{PAuCl}$ and its encapsulated form affect morphology of human CRC cell line. Representative images of data shown in Table 1. Scale bar $=50 \mu \mathrm{m}$

an increase of nucleus/cytoplasm ratio (control: $1.17 \pm 0.09$ vs nano-Et ${ }_{3} \mathrm{PAuCl}$ : $1.29 \pm 0.08$; $\mathrm{p}=0.086$ ) (Table 1). As expected, more pronounced effects were registered with $200 \mathrm{nM}^{\text {of }} \mathrm{Et}_{3} \mathrm{PAuCl}$ or nano- $\mathrm{Et}_{3} \mathrm{PAuCl}$ treatment (data not shown).

Autophagy plays important roles in cell survival as well as in the regulation of cell death. To investigate whether the activation of autophagy contributes to the anti-proliferative effect of nano- $\mathrm{Et}_{3} \mathrm{PAuCl}$, the presence of vacuoles in CRC cells was examined. HCT116 cells were treated for $24 \mathrm{~h}$ with $\mathrm{Et}_{3} \mathrm{PAuCl}$ or nano$\mathrm{Et}_{3} \mathrm{PAuCl}(100 \mathrm{nM})$ and the number of vacuoles per cell was measured. Although HCT-116 cells showed a conspicuous basal level of vacuoles, the number of vacuoles per cell was almost doubled after treatment with $\mathrm{Et}_{3} \mathrm{PAuCl}$ or with its encapsulated form suggesting the occurrence of a possible autophagic process, too (control: $5.21 \pm 0.50$ vs $\mathrm{Et}_{3} \mathrm{PAuCl} 9.62 \pm 0.79$ $\mathrm{p}=0.0005$; control: $5.21 \pm 0.50$ vs nano- $\mathrm{Et}_{3} \mathrm{PAuCl}$ $9.52 \pm 1.96, \mathrm{p}=0.0016$ ) (Table 2).

At the same time, we registered an increase also in terms of the percentage of CRC cells with vacuoles, that significantly increases after the treatment with 
Table 2 Morphology alterations of the compounds, given at a comparative concentration value (100 nM) on HCT-116 cells, after $24 \mathrm{~h}$ of treatment

\begin{tabular}{llll}
\hline Sample & Cells diameter $(\mu \mathrm{m})$ & Nucleus/cytoplasm ratio & Vacuoles per cell \\
\hline Control & $26.03 \pm 0.18$ & $1.17 \pm 0.09$ & $5.21 \pm 0.50$ \\
$\mathrm{Et}{ }_{3} \mathrm{PAuCl}(100 \mathrm{nM})$ & $24.57 \pm 0.28^{* *}$ & $1.05 \pm 0.08$ & $9.62 \pm 0.79^{* *}$ \\
$\mathrm{Nano}-\mathrm{Et}{ }_{3} \mathrm{PAuCl}(100 \mathrm{nM})$ & $22.85 \pm 0.46^{* *}$ & $1.29 \pm 0.08$ & $9.52 \pm 1.96^{* *}$ \\
\hline
\end{tabular}

both $\mathrm{Et}_{3} \mathrm{PAuCl}$ or nano- $\mathrm{Et}_{3} \mathrm{PAuCl}$ (control: $23 \% \pm 0.7$ vs $\mathrm{Et}_{3} \mathrm{PAuCl} 34 \% \pm 3.0, \mathrm{p}=0.07$; control: $23 \% \pm 0.7$ vs nano- $\mathrm{Et}_{3} \mathrm{PAuCl} 33 \% \pm 3.5$, $\mathrm{p}=0.10$ ). Conversely, no increase of the size of vacuoles was registered. Such effects are still more evident in CRC cells treated with $200 \mathrm{nM}$ of the two compounds (data not shown); at this latter concentration, an increase of vacuoles dimension also emerged.

Also, we investigated in detail the effects of $\mathrm{Et}_{3} \mathrm{PAuCl}$ and of its encapsulated form on HCT-116 cell cycle distribution, studying the percentage of cells on the different phases of the cell cycle by propidium iodide staining. HCT-116 cells treated for $24 \mathrm{~h}$ with $\mathrm{Et}_{3} \mathrm{PAuCl}$ or nano-Et ${ }_{3} \mathrm{PAuCl}$ showed an enhanced percentage of cells in the $\mathrm{G} 2 / \mathrm{M}$ phase associated to a reduced percentage of cells in $\mathrm{S}$ phase; this effect seems more evident in cells treated with nano$\mathrm{Et}_{3} \mathrm{PAuCl}$ but is not statistically significant (percentage of cells in $\mathrm{S}$ phase control: $30.59 \pm 5.10 \mathrm{vs}$ $\mathrm{Et}_{3} \mathrm{PAuCl} \quad 24.97 \pm 1.61, \quad \mathrm{p}=0.40 ; \quad$ control: $30.59 \pm 5.10 \quad v s \quad$ nano-Et ${ }_{3} \mathrm{PAuCl} 21.81 \pm 2.14$, $\mathrm{p}=0.22$ ) (Table 3 and Fig. 4a).

Thus, we observed the induction of an evident G2/ $\mathrm{M}$ arrest, indicating that, in both cases, block the cell cycle in CRC cells impairing HCT-116 cell proliferation. Based on these premises, we studied the effects of long-term exposure of $\mathrm{HCT}-116$ cells to $\mathrm{Et}_{3} \mathrm{PAuCl}$ or nano- $\mathrm{Et}_{3} \mathrm{PAuCl}$ in a $2 \mathrm{D}$ cell proliferation assay. $24 \mathrm{~h}$ after seeding HCT-116 the free gold complex or nano- $\mathrm{Et}_{3} \mathrm{PAuCl}$ were added at different concentrations
$(0,100,200 \mathrm{nM})$ and the number of live cells was assessed at different times ( $24 \mathrm{~h}, 48 \mathrm{~h}$ and $72 \mathrm{~h}$ ). Data collected showed that nano- $\mathrm{Et}_{3} \mathrm{PAuCl}$ maintained appreciable cytotoxic properties; therefore, the combination with PLGA-PEG nanoparticles preserved the antiproliferative activity of chloro(triethylphosphine)gold(I) (Fig. 4b). To gain further insight on the antiproliferative activity on CRC cells, the effects of $\mathrm{Et}_{3} \mathrm{PAuCl}$ and its encapsulated formulation, were confirmed in HCT-116 cells cultured in a threedimensional (3D) model. The development of 3D in vitro tumor models more accurately represents human solid tumors growth. Thus, we assembled 3D tumor spheroids from HCT-116 cell line, and we exposed them to both $\mathrm{Et}_{3} \mathrm{PAuCl}$ and nano- $\mathrm{Et}_{3} \mathrm{PAuCl}$ at $200 \mathrm{nM}$. At increasing incubation times, the effects appeared clear in terms of spheroid relative volumes. At $\mathrm{t}=96 \mathrm{~h}, \mathrm{t}=120 \mathrm{~h}, \mathrm{t}=144 \mathrm{~h}$, both $\mathrm{Et}_{3} \mathrm{PAuCl}$ and nano- $\mathrm{Et}_{3} \mathrm{PAuCl}$ showed a statistically significant tumor growth inhibition compared to control samples (see figure legends for detailed values). In particular, nano- $\mathrm{Et}_{3} \mathrm{PAuCl}$ was more effective than $\mathrm{Et}_{3} \mathrm{PAuCl}$ at longer time points $\left(\mathrm{t}=120 \mathrm{~h}: \mathrm{Et}_{3} \mathrm{PAuCl} 2.46 \pm 0.18\right.$ $v s$ nano-Et ${ }_{3} \mathrm{PAuCl} 1.88 \pm 0.15, \mathrm{p}=0.047$ ) (Fig. $4 \mathrm{c}$, d). These data proved that the free compound and its encapsulated form kept their effects on HCT-116 in vitro both in monolayer and in $3 \mathrm{D}$ tumor cell culture assays; furthermore, the encapsulation likely enhanced gold complex availability inside the 3D structures.

Table 3 Study of cell cycle distribution of HCT-116 cells, after $24 \mathrm{~h}$ of treatment with $\mathrm{Et}_{3} \mathrm{PAuCl}$ and its encapsulated form

\begin{tabular}{llll}
\hline Cell cycle phase & Control & $\mathrm{Et}_{3} \mathrm{PAuCl}(100 \mathrm{nM})$ & $\mathrm{Nano}_{\mathrm{Et}} \mathrm{PAuCl}(100 \mathrm{nM})$ \\
\hline $\mathrm{G}_{0} / \mathrm{G}_{1}$ & $31.18 \pm 5.02$ & $31.24 \pm 9.11$ & $29.58 \pm 7.61$ \\
$\mathrm{~S}$ & $30.59 \pm 5.10$ & $24.97 \pm 1.61$ & $21.81 \pm 2.14$ \\
$\mathrm{G}_{2} / \mathrm{M}$ & $38.23 \pm 8.62$ & $43.79 \pm 10.70$ & $48.60 \pm 9.74$ \\
\hline
\end{tabular}

Data are reported as percentage of cells on each phase of the cell cycle and as means \pm SEM of four independent experiments 

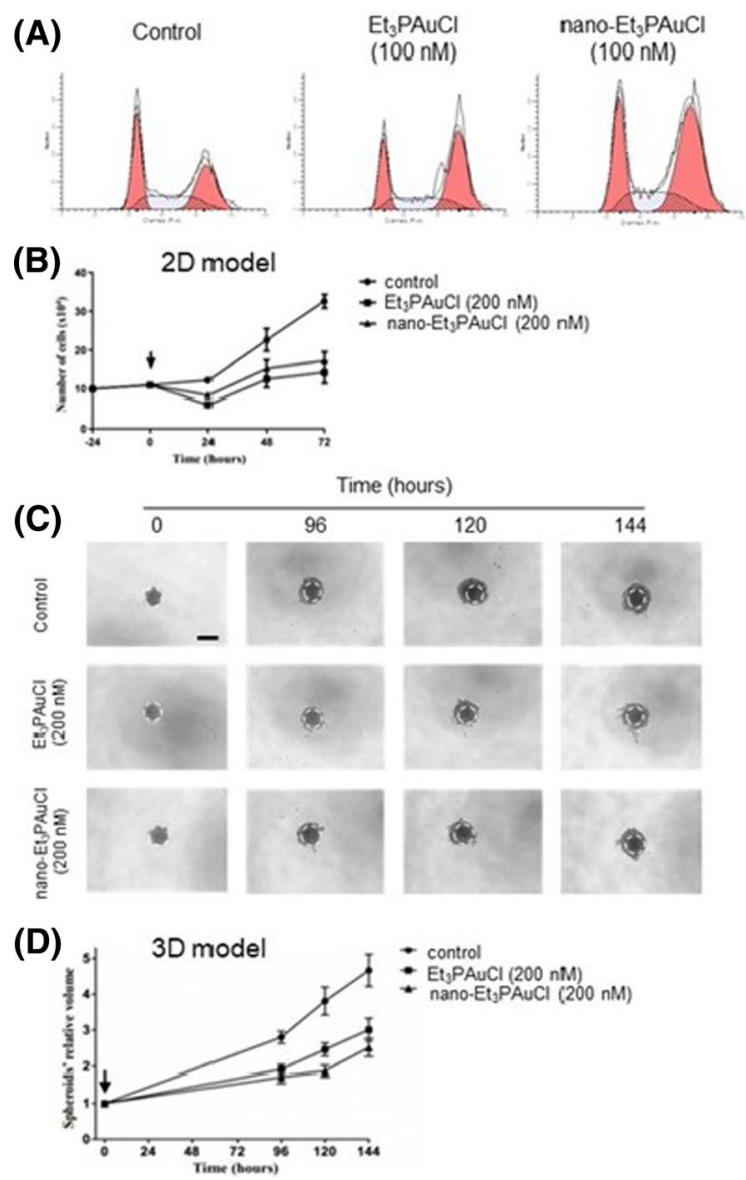

Fig. 4 Analysis of the $\mathrm{Et}_{3} \mathrm{PAuCl}$ and its encapsulated form on cell cycle distribution and their effects in $2 \mathrm{D}$ and $3 \mathrm{D}$ cell cultures. a: Representative histograms of data shown on Table 2. b Effects on HCT-116 cells proliferation after incubation with $200 \mathrm{nM} \mathrm{Et}_{3} \mathrm{PAuCl}$ and its encapsulated formulation for 24, 48 and $72 \mathrm{~h}$. The determination of viable cell was calculated using Trypan Blue exclusion test. Results report average value of three independent experiments \pm SEM. The significance of differences between groups was calculated through $t$ test. ${ }^{*} \mathrm{p}<0.05$; ** $\mathrm{p}<0.01$. (Ctrl vs $\mathrm{Et}_{3} \mathrm{PAuCl} 24 \mathrm{~h}, \mathrm{p}=0.0011$; ctrl vs nano$\mathrm{Et}_{3} \mathrm{PAuCl} 24$ h, p = 0.0058; ctrl vs $\mathrm{Et}_{3} \mathrm{PAuCl} 48$ h, p = 0.047; ctrl $v s \mathrm{Et}_{3} \mathrm{PAuCl} 72 \mathrm{~h}, \mathrm{p}=0.0053$; ctrl $v s$ nano- $\mathrm{Et}_{3} \mathrm{PAuCl} 72 \mathrm{~h}$, $\mathrm{p}=0.0066$ ). $\mathbf{c}$ Typical original spheroid images of various time conditions. Scale bar $=100 \mu \mathrm{m}$. d Histogram pertinent to relative volume of $\mathrm{HCT} 116$ spheroids exposed to $\mathrm{Et}_{3} \mathrm{PAuCl}$ and its encapsulated form ( 0 and $200 \mathrm{nM})$ for $0,96,120,144 \mathrm{~h}$. This study used the high-throughput image analysis software SpheroidSizer. Data are given by three independent experiments \pm SEM. Spheroid volumes were investigated by Matlab as reported in the "Methods" section. The significance of differences between groups was calculated through $t$ test. ${ }^{*} \mathrm{p}<0.05 ;{ }^{* *} \mathrm{p}<0.01$. (Ctrl vs $\mathrm{Et}_{3} \mathrm{PAuCl} 96 \mathrm{~h}, \mathrm{p}=0.0012 ; \mathrm{ctrl}$ vs nano-Et ${ }_{3} \mathrm{PAuCl} 96 \mathrm{~h}, \mathrm{p}=0.0009$; ctrl vs $\mathrm{Et}_{3} \mathrm{PAuCl} 120 \mathrm{~h}$, $\mathrm{p}=0.0083$; ctrl vs nano-Et ${ }_{3} \mathrm{PAuCl} 120 \mathrm{~h}, \mathrm{p}=0.0026$; ctrl $v s$ $\mathrm{Et}_{3} \mathrm{PAuCl} 144 \mathrm{~h}, \mathrm{p}=0.0112$; ctrl vs nano-Et ${ }_{3} \mathrm{PAuCl} 144 \mathrm{~h}$, $\mathrm{p}=0.0023$ )
At this point, since AF has been confirmed to exert significant antitumor activities (Marzo et al. 2017), we decided to explore if the study compounds do affect some relevant signaling pathways, such as AKT and ERK, whose kinases take part in the regulation of cell proliferation, cell growth and survival. The results showed that both $\mathrm{Et}_{3} \mathrm{PAuCl}$ and nano- $\mathrm{Et}_{3} \mathrm{PAuCl}$ induced, after $24 \mathrm{~h}$ of treatment, a remarkable downregulation of phosphorylation of AKT; in addition, nano- $\mathrm{Et}_{3} \mathrm{PAuCl}$, but not $\mathrm{Et}_{3} \mathrm{PAuCl}$, was also found to affect the phosphorylation levels of ERK (Fig. 5).

This difference could be induced from the increased stability of the nanoformulation, in fact our data showed that, after $24 \mathrm{~h}$ of observation, more than $90 \%$ of the compound was retained. Moreover, encapsulation process might lead to an improved pharmacological profile, most probably due to a higher lipophilicity of nano-Et ${ }_{3} \mathrm{PAuCl}$ tanks to the effect of internalization into PLGA-PEG NPs.

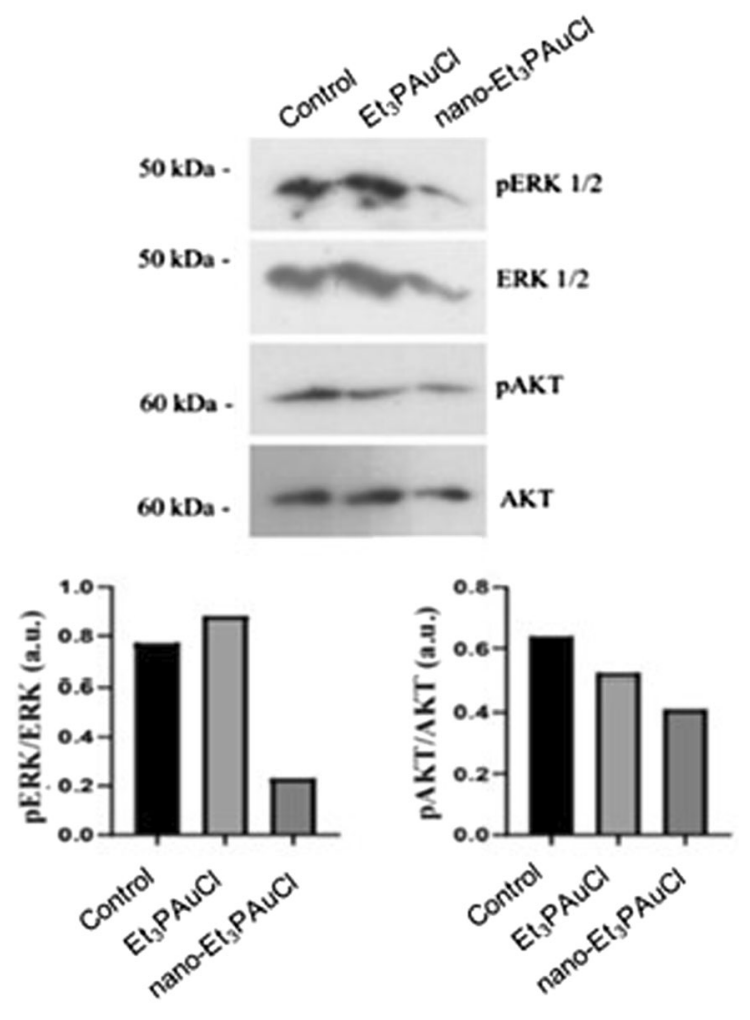

Fig. 5 Nano-Et ${ }_{3} \mathrm{PAuCl}$ antitumoral activity is ERK and AKT mediated. Expression of ERK and AKT in HCT116 cells after a single treatment with $\mathrm{Et}_{3} \mathrm{PAuCl}$ and nano- $\mathrm{Et}_{3} \mathrm{PAuCl}$ at $200 \mathrm{nM}$, for $24 \mathrm{~h}$. The corresponding densitometric data are reported on the bottom 


\section{Conclusions}

Nowadays, the gold(I) complex AF is the leading experimental anticancer agent of the family of goldbased drugs and is currently undergoing a few clinical trials (Roder and Thomson 2015). In turn, this accession of AF to clinical trials has triggered new attention on a few AF-related complexespreviously prepared and characterized. Here, we have focused our attention on $\mathrm{Et}_{3} \mathrm{PAuCl}$ (Marzo et al. 2017, 2018), a compound where the thiosugar ligand of $\mathrm{AF}$ is replaced by a chloride ligand. Specifically, we wondered whether a nanoformulation of $\mathrm{Et}_{3} \mathrm{PAuCl}$, in particular its encapsulation into PLGA-PEG nanoparticles, might result into improved pharmacological and anticancer performances. Notably, $\mathrm{Et}_{3} \mathrm{PAuCl}$ and other AF-related complexesbearing different substituents had been previously reported to produce important anticancer actions in vitro and in vivo on a variety of cancer cell lines (Marzo et al. 2017, 2019). Accordingly, we proceeded with the preparation of a nanoformulation of $\mathrm{Et}_{3} \mathrm{PAuCl}$ : the well-known PLGA-PEG nanoparticles were chosen for the encapsulation process. The size of the nanoparticles was set around a diameter of $68 \mathrm{~nm}$. The above nanoformulation turned out to be stable in a physiological medium: in fact, just a minor percentage of $\mathrm{Et}_{3} \mathrm{PAuCl}$ is released after $24 \mathrm{~h}$ of observation with more than $90 \%$ of the compound retained. We performed a number of biological tests on the above $\mathrm{Et}_{3} \mathrm{PAuCl}$ loaded nanoparticles (nano- $\mathrm{Et}_{3} \mathrm{PAuCl}$ ) in comparison to free $\mathrm{Et}_{3} \mathrm{PAuCl}$ in a HCT-116 CRC cell line. At first, we wanted to establish whether nanoformulated $\mathrm{Et}_{3} \mathrm{PAuCl}$ retains the cytotoxic properties of free $\mathrm{Et}_{3} \mathrm{PAuCl}$. Experiments carried out in 2D and 3D CRC cell models highlighted that anti-proliferative properties were retained; in particular, nano- $\mathrm{Et}_{3} \mathrm{PAuCl}$ was more effective than $\mathrm{Et}_{3} \mathrm{PAuCl}$ at longer time points against the $3 \mathrm{D}$ cancer model likely due to a more favorable kinetic of release of the pharmacologically active fragment $\left[\mathrm{Au}\left(\mathrm{PEt}_{3}\right)\right]^{+}$. This latter aspect is of particular importance because, this augmented anticancer effects, is exerted on the 3D HCT-116 model better reproducing the cancer environment. The antiproliferative effects of $\mathrm{Et}_{3} \mathrm{PAuCl}$ and nano- $\mathrm{Et}_{3} \mathrm{PAuCl}$ in CRC cells are likely due to a dual effect on apoptosis and autophagy. Also, of interest, is the significant difference in terms of signaling pathways related to cell survival affected by $\mathrm{Et}_{3} \mathrm{PAuCl}$ or nano-
$\mathrm{Et}_{3} \mathrm{PAuCl}$ : indeed, both inhibit efficiently the AKT pathway, while only nano- $\mathrm{Et}_{3} \mathrm{PAuCl}$ is able to inhibit the ERK pathway. The fate of PLGA-PEG nanoparticles could be traced thanks to the presence of an attached fluorophore. We observed that the nanoparticles are progressively internalized in CRC cells over $4 \mathrm{~h}$ observation. The time-dependence of the internalization process was also independently confirmed by ICP-AES experiments. In conclusion, our results suggest that nano- $\mathrm{Et}_{3} \mathrm{PAuCl}$ alone elicits cytotoxic effects in CRC cells most likely through inhibition of different signaling pathways, i.e. ERK and AKT, improving the antitumoral activity of the free gold complex $\mathrm{Et}_{3} \mathrm{PAuCl}$. Indeed, the data we collected on CRC cell line suggest a peculiar efficacy of nano$\mathrm{Et}_{3} \mathrm{PAuCl}$ on ERK pathway, which is almost totally inhibited.

A previous mechanistic investigation conducted by our research group had revealed that $\mathrm{Et}_{3} \mathrm{PAuCl}$, analogously to $\mathrm{AF}$, inhibits thioredoxin reductase (TrxR) (Marzo et al. 2017) and it was recently demonstrated that targeting TrxR inhibits the growth of cancer cells by inducing apoptosis through activation of the MAPK signaling pathway and, additionally, by the inhibition of AKT/mTOR pathway that in turn regulates autophagy (Lei et al. 2018; Comfort et al. 2011). In addition, AF has been reported to induce ERK and AKT inactivation in lung cancer cells (Fan et al. 2014).

These recent findings nicely support our preliminary data on nano- $\mathrm{Et}_{3} \mathrm{PAuCl}$.

Acknowledgements D.C. gratefully acknowledges AIRC (Associazione Italiana per la Ricerca sul Cancro) for the financial support (one-year Fellowship for Italy_Project Code: 22294 and 2-year fellowship for Italy-Project Code: 23852). L.M. and A.P. gratefully acknowledge AIRC (Associazione Italiana per la Ricerca sul Cancro) and ECRF (Ente Cassa di Risparmio di Firenze) for the financial support (AIRCECRF19650). Authors thank CSGI (Department of Chemistry, University of Florence) for DLS experiments. T.M. and A.P. thank University of Pisa (Rating Ateneo 2019 and 2020). T.M. and A.P. thank Beneficentia Stiftung (Vaduz) for supporting projects BEN2019/48 and BEN2020/34, respectively. This work is also supported by the University of Pisa under the "PRA-Progetti di Ricerca di Ateneo" Institutional Research Grants_Project no. PRA_2020_58 "Agenti innovative e nanosistemi per target molecolari nell'ambito dell'oncologia di precisione" to TM.

Funding Open access funding provided by Università di Pisa within the CRUI-CARE Agreement. 
!Open Access This article is licensed under a Creative Commons Attribution 4.0 International License, which permits use, sharing, adaptation, distribution and reproduction in any medium or format, as long as you give appropriate credit to the original author(s) and the source, provide a link to the Creative Commons licence, and indicate if changes were made. The images or other third party material in this article are included in the article's Creative Commons licence, unless indicated otherwise in a credit line to the material. If material is not included in the article's Creative Commons licence and your intended use is not permitted by statutory regulation or exceeds the permitted use, you will need to obtain permission directly from the copyright holder. To view a copy of this licence, visit http://creativecommons.org/licenses/by/4.0/.

\section{References}

Afshari M, Derakhshandeh K, Hosseinzadeh L (2014) Characterisation, cytotoxicity and apoptosis studies of methotrexate-loaded PLGA and PLGA-PEG nanoparticles. J Microencapsul 31:239-245. https://doi.org/10.3109/ 02652048.2013 .834991

Anari E, Akbarzadeh A, Zarghami N (2016) Chrysin-loaded PLGA-PEG nanoparticles designed for enhanced effect on the breast cancer cell line. Artif Cells Nanomedicine Biotechnol 44:1410-1416. https://doi.org/10.3109/ 21691401.2015.1029633

Bombardier C, Ware J, Russell IJ et al (1986) Auranofin therapy and quality of life in patients with rheumatoid arthritis. Results of a multicenter trial. Am J Med 81:565-578. https://doi.org/10.1016/0002-9343(86)90539-5

Chen W, Wong C, Vosburgh E et al (2014) High-throughput image analysis of tumor spheroids: a user-friendly software application to measure the size of spheroids automatically and accurately. J Vis Exp 89:51639. https://doi.org/10. $3791 / 51639$

Cheng J, Teply BA, Sherifi I et al (2007) Formulation of functionalized PLGA-PEG nanoparticles for in vivo targeted drug delivery. Biomaterials 28:869-876. https://doi.org/ 10.1016/j.biomaterials.2006.09.047

Cirri D, Pillozzi S, Gabbiani C et al (2017) PtI2(DACH), the iodido analogue of oxaliplatin as a candidate for colorectal cancer treatment: chemical and biological features. Dalton Trans 46:3311-3317. https://doi.org/10.1039/c6dt03867k

Comfort KK, Maurer EI, Braydich-Stolle LK, Hussain SM (2011) Interference of silver, gold, andiron oxide nanoparticles on epidermal growth factor signal transduction in epithelial cells. ACS Nano 5(12):10000-10008. https://doi.org/10.1021/nn203785a

Fan C, Zheng W, Fu X et al (2014) Enhancement of auranofininduced lung cancer cell apoptosis by selenocystine, a natural inhibitor of TrxR1 in vitro and in vivo. Cell Death Dis 5:e1191. https://doi.org/10.1038/cddis.2014.132

Johnstone TC, Suntharalingam K, Lippard SJ (2016) The next generation of platinum drugs: targeted Pt(II) agents, nanoparticle delivery, and $\mathrm{Pt}(\mathrm{IV})$ prodrugs. Chem Rev 116:3436-3486. https://doi.org/10.1021/acs.chemrev. $5 \mathrm{~b} 00597$
Lei H, Wang G, Zhang J, Han Q (2018) Inhibiting TrxR suppresses liver cancer by inducing apoptosis and eliciting potent antitumor immunity. Oncol Rep 40:3447-3457. https://doi.org/10.3892/or.2018.6740

Li H, Hu J, Wu S et al (2016) Auranofin-mediated inhibition of $\mathrm{PI} 3 \mathrm{~K} / \mathrm{AKT} / \mathrm{mTOR}$ axis and anticancer activity in nonsmall cell lung cancer cells. Oncotarget 7:3548-3558. https://doi.org/10.18632/oncotarget.6516

Magherini F, Fiaschi T, Valocchia E et al (2018) Antiproliferative effects of two gold(I)-N-heterocyclic carbene complexes in A2780 human ovarian cancer cells: a comparative proteomic study. Oncotarget 9:28042-28068. https://doi. org/10.1632/oncotarget.25556

Marzo T, Cirri D, Gabbiani C et al (2017) Auranofin, $\mathrm{Et}_{3} \mathrm{PAuCl}$, and $\mathrm{Et}_{3} \mathrm{PAuI}$ are highly cytotoxic on colorectal cancer cells: a chemical and biological study. ACS Med Chem Lett 8:997-1001. https://doi.org/10.1021/acsmedchemlett. $7 \mathrm{~b} 00162$

Marzo T, Cirri D, Pollini S et al (2018) Auranofin and its analogues show potent antimicrobial activity against multidrug-resistant pathogens: structure-activity relationships. Chem Med Chem 13:2448-2454. https://doi.org/10.1002/ cmdc. 201800498

Marzo T, Massai L, Pratesi A et al (2019) Replacement of the thiosugar of auranofin with iodide enhances the anticancer potency in a mouse model of ovarian cancer. ACS Med Chem Lett 10:656-660. https://doi.org/10.1021/ acsmedchemlett.9b00007

Merlino A, Marzo T, Messori L (2017) Protein metalation by anticancer metallodrugs: a joint ESI MS and XRD investigative strategy. Chem Eur J 23:6942-6947. https://doi. org/10.1002/chem.201605801

Micale N, Schirmeister T, Ettari R et al (2014) Selected cytotoxic gold compounds cause significant inhibition of $20 \mathrm{~S}$ proteasome catalytic activities. J Inorg Biochem 141:79-82. https://doi.org/10.1016/j.jinorgbio.2014.08. 001

Mirabelli CK, Johnson RK, Sung CM et al (1985) Evaluation of the in vivo antitumor activity and in vitro cytotoxic properties of auranofin, a coordinated gold compound murine tumor models. Cancer Res 45(1):32-39

Park H, Yang J, Seo S et al (2008) Multifunctional nanoparticles for photothermally controlled drug delivery and magnetic resonance imaging enhancement. Small 4:192-196. https:// doi.org/10.1002/smll.200700807

Pillozzi S, D'Amico M, Bartoli G et al (2018) The combined activation of $\mathrm{K}$ Ca 3.1 and inhibition of $\mathrm{K}$ v 11.1/hERG1 currents contribute to overcome cisplatin resistance in colorectal cancer cells. Br J Cancer 118:200-212. https:// doi.org/10.1038/bjc.2017.392

Poursharifi M, Wlodarczyk MT, Mieszawska AJ (2018) Nanobased systems and biomacromolecules as carriers for metallodrugs in anticancer therapy. Inorganics 7:2. https:// doi.org/10.3390/inorganics7010002

Pratesi A, Gabbiani C, Michelucci E et al (2014) Insights on the mechanism of thioredoxin reductase inhibition by gold $\mathrm{N}$-heterocyclic carbene compounds using the synthetic linear selenocysteine containing C-terminal peptide hTrxR(488-499): an ESI-MS investigation. J Inorg Biochem 136:161-169. https://doi.org/10.1016/j.jinorgbio. 2014.01.009 
Pratesi A, Cirri D, Ciofi L, Messori L (2018) Reactions of auranofin and its pseudohalide derivatives with serum albumin investigated through ESI-Q-TOF MS. Inorg Chem 57:10507-10510. https://doi.org/10.1021/acs.inorgchem. $8 \mathrm{~b} 02177$

Roder C, Thomson MJ (2015) Auranofin: repurposing an old drug for a golden new age. Drugs R\&D 15:13-20. https:// doi.org/10.1007/s40268-015-0083-y

Scalcon V, Bindoli A, Rigobello MP (2018) Significance of the mitochondrial thioredoxin reductase in cancer cells: an update on role, targets and inhibitors. Free Radic Biol Med 127:62-79

Sutton BM, Mcgusty E, Walz DT, Dimartino MJ (1972) Oral gold. antiarthritic properties of alkylphosphinegold coordination complexes. J Med Chem 15:1095-1098. https:// doi.org/10.1021/jm00281a001

Tian J, Min Y, Rodgers Z et al (2017) Co-delivery of paclitaxel and cisplatin with biocompatible PLGA-PEG nanoparticles enhances chemoradiotherapy in non-small cell lung cancer models. J Mater Chem B 5:6049-6057. https://doi.org/10.1039/c7tb01370a

Tolbatov I, Cirri D, Marchetti L et al (2020) Mechanistic insights into the anticancer properties of the auranofin analog $\mathrm{Au}(\mathrm{PEt} 3) \mathrm{I}$ : a theoretical and experimental study. Front Chem 8:812. https://doi.org/10.3389/fchem.2020. 00812

Zoppi C, Messori L, Pratesi A (2020) ESI MS studies highlight the selective interaction of auranofin with protein free thiols. Dalton Trans 49:5906-5913. https://doi.org/10. 1039/d0dt00283f

Publisher's Note Springer Nature remains neutral with regard to jurisdictional claims in published maps and institutional affiliations. 